\title{
Effects of propolis on warfarin efficacy
}

\author{
Esin Akbay ${ }^{1}$, Çiğdem Özenirler ${ }^{1}$, Ömür Gençay Çelemli ${ }^{1}$, Ahmet Baris Durukan² ${ }^{2}$ Mehmet Ali Onur ${ }^{1}$, \\ Kadriye Sorkun ${ }^{1}$
}

${ }^{1}$ Department of Biology, Faculty of Science, Hacettepe University, Ankara, Turkey

${ }^{2}$ Department of Cardiovascular Surgery, Medical Park, Private Uşak Hospital, Uşak, Turkey

Kardiochirugia i Torakochirurgia Polska 2017; 14 (1): 43-46

\begin{abstract}
Introduction: Warfarin is commonly used to avoid thromboembolism, predominantly for cardiovascular pathologies. However, the consumption of several herbal products is not permitted during its use due to the associated interactions. Propolis is a popular phytotherapy product made by honey bees. The use of propolis has been dramatically increasing in recent times.

Aim: To evaluate the possible interactions between propolis and warfarin in a mouse model with determination of the international normalized ratio (INR) values.

Material and methods: CD-1 mice were employed in the experimental model. The mice were warfarinized, and propolis was administered simultaneously. The INR values were obtained. All animals were sacrificed at the end of the study.

Results: The baseline INR value was $0.8 \pm 0.1$. After $72 \mathrm{~h}$, the INR value increased as expected. The INR value was $7.28 \pm 1.08$ in the control group and $5.8 \pm 2.88$ in the propolis group. At the end of the study, the INR value was $1.3 \pm 0.37$. Propolis interacted with warfarin and caused a decrease in the INR value.

Conclusions: Propolis interactions, especially with warfarin, should be kept in mind and further studied. Healthcare specialists should be aware of this possible interaction between warfarin and propolis and inform patients about it.

Key words: propolis, warfarin, international normalized ratio, CD-1 mice, Coumadin.
\end{abstract}

\section{Introduction}

Recently, the prevalence of heart failure (HF) has increased dramatically. The population is getting older; therefore, the incidence of HF has increased. At the same time, medical therapy for $\mathrm{HF}$ is progressing [1].

The HF is associated with a risk of thromboembolism, which often results in the patient's death. In order to prevent this, oral anticoagulants are administered. One very effective agent used for this purpose is the vitamin $\mathrm{K}$ antagonist warfarin (Coumadin, Turkey). Warfarin therapy is

\section{Streszczenie}

Wstęp: Warfaryna jest często używana w celu zapobiegania incydentom zakrzepowo-zatorowym, głównie w schorzeniach sercowo-naczyniowych. W trakcie jej stosowania przyjmowanie części produktów ziołowych jest zabronione ze względu na interakcje lekowe. Propolis to popularny produkt ziołoleczniczy wytwarzany przez pszczoły miodne. Jego użycie ostatnio zwiększa się gwałtownie.

Cel: Zidentyfikowanie możliwych interakcji pomiędzy propolisem a warfaryną w modelu mysim i ustalenie wartości międzynarodowego współczynnika znormalizowanego (INR).

Materiał i metody: W eksperymencie wykorzystano myszy CD-1. Myszom podawano jednocześnie warfarynę i propolis, monitorując wartości INR. Wszystkie zwierzęta poddano eutanazji po zakończeniu badania.

Wyniki: Wyjściowa wartość INR wynosiła 0,8 $\pm 0,1$. Po 72 godzinach, zgodnie z oczekiwaniami, nastąpit jej wzrost do 7,28 $\pm 1,08$ w grupie kontrolnej i 5,8 $\pm 2,88$ w grupie przyjmującej propolis. Na końcu badania wartość INR wynosiła 1,3 $\pm 0,37$. Propolis wszedt w interakcję z warfaryną i spowodował zmniejszenie wartości INR.

Wnioski: Interakcje propolisu, zwłaszcza z warfaryną, są tematem wartym uwagi i dalszych badań. Specjaliści służby zdrowia powinni być świadomi możliwych interakcji pomiędzy warfaryną a propolisem i informować o nich pacjentów.

Słowa kluczowe: propolis, warfaryna, międzynarodowy współczynnik znormalizowany, myszy CD-1, Coumadin.

recommended in order to thin the blood and minimize the risk of stroke [2]. Sometimes daily dietary habits affect the drug's metabolic pathway; therefore, it is crucial to pay attention to diet while using warfarin.

Propolis (bee glue) is a sticky, dark-colored material that honeybees collect from living plants, mix with wax, and use in the construction of their nests. Its resistance against micro-organisms is one of its essential characteristics, and it has been used by human beings since ancient times for its pharmaceutical properties [3].

Address for correspondence: Esin Akbay PhD, Department of Biology, Faculty of Science, Hacettepe University, Beytepe, 06800 Ankara, Turkey, phone: +90 5064900042, e-mail: akbayesin@gmail.com

Received: 10.01.2017, accepted: 13.03.2017. 
The chemical composition of propolis depends on the properties of the collection site. Bees collect it from different source plants in different ecosystems by choosing appropriate representatives of the local flora. The different plant choices of bees in different habitats complicate propolis standardization [4].

\section{Aim}

In this study, we aimed to test the effects of propolis on warfarin therapy in a mouse model and determine the international normalized ratio (INR) values.

\section{Material and methods \\ Animals}

Male CD-1 mice were used with the approval of the Animal Care and Use Committee of Hacettepe University (permit no. 2016/5-10); the tests were carried out in accordance with the National Guidelines for the Use and Care of Laboratory Animals. After twenty 30-40 g CD-1 mice were purchased from the Animal Laboratory Unit of Hacettepe University, they were allowed to get used to the conditions of the laboratory for 1 week. The animals were housed separately in polypropylene cages with a 12-12 h light-dark cycle.

\section{Experimental design}

The mice were randomly divided into four groups containing five animals per group. The first set of mice $(n=5)$ formed the control group used to determine the baseline INR. The second group received propolis, and the third group was administered Coumadin by oral gavage. The fourth group was treated with Coumadin, which after a while was followed with propolis by oral gavage. All administrations were done over eight days starting at 2:00 p.m. On the $8^{\text {th }}$ day, all animals were sacrificed in accordance with the ethical rules.

The selected dose for the application of propolis was $100 \mathrm{mg} / \mathrm{kg} /$ day (20 $\mu \mathrm{l} /$ day) [5]. In mice, the average daily warfarin dose for a body weight of $40 \mathrm{~g}$ should be $0.08 \mathrm{mg}$ [6]. A Coumadin tablet contains $5 \mathrm{mg}$ of warfarin. One tablet of Coumadin was dissolved in $20 \mathrm{ml}$ of tap water, and this was used as a stock solution. Each mouse in the relevant groups (third and fourth) received $320 \mu$ l of the stock solution.

\section{Preparation of ethanol extract of propolis (EEP)}

We used a local honey bee product from Düzce, Turkey. Frozen propolis was ground and dissolved in $70 \%$ ethanol $(1: 3)$. This mixture was kept in a refrigerator for 2 weeks in a tightly closed bottle. The supernatant was filtered twice with Whatman no. 4 and 1 filter papers (Whatman International Ltd, Maidstone, UK). The filtered solution was an ethanol extract of propolis (EEP), and the final supernatant was analyzed using gas chromatography-mass spectrometry (GC-MS) [7].

\section{Determination of volatile compounds in propolis samples by gas chromatography and mass spectrometry (GC-MS)}

The GC-MS analysis of the EEP samples was performed using a 6890N gas chromatograph from Agilent (Palo Alto, CA, USA) coupled with a mass detector (MS5973, Agilent) equipped with a DB-5 MS capillary column $(30 \mathrm{~m} \times 0.25 \mathrm{~mm}$; film thickness: $0.25 \mu \mathrm{m}$ ). Helium was used as the carrier gas at a flow rate of $1 \mathrm{ml} / \mathrm{min}$.

Organic compounds in propolis samples were identified in the Wiley/NIST Mass Spectral Library [8].

\section{INR value measurements}

Propolis and Coumadin were orally administered to the mice daily for eight days. Blood samples were collected carefully in accordance with the ethical permission from $72 \mathrm{~h}$ after the first administration of chemicals every day at 9:00 a.m. The INR was measured on the $4^{\text {th }}, 6^{\text {th }}$, and $8^{\text {th }}$ days with an INR device called the CouguChek XS System (Roche Diagnostics Japan, Tokyo). The reference values for mean INR values in CD-1 mice have been published elsewhere [9].

\section{Statistical analysis}

The results are presented as mean \pm SD. Statistical data analysis was conducted with $\mathrm{R}$ software [10]. One-way analysis of variance (ANOVA) was performed and followed by Tukey's test to determine statistical significance for multiple comparisons. A difference was considered statistically significant at $p<0.05$.

\section{Results}

\section{Chemical composition of propolis}

The main components of propolis, rich in alcohol, aldehydes, and flavonoids, are summarized in Table I.

\section{Animal experiment}

In this study, CD-1 mice were preferred due to the existence of previous research using the same species [9]. Oral administration of both warfarin and propolis solution to each mouse (except the control group) was performed by gavage. All mice were sacrificed on the $8^{\text {th }}$ day of the experiment. No deaths occurred during the study.

\section{Changes in INR values}

The first blood samples were collected $72 \mathrm{~h}$ after the first administration, and INR values were measured. The mean INR value in the control group (no warfarin or propolis treatment) was determined as $0.8 \pm 0.1$. The INR results in the propolis group were the same as in controls; no changes were observed. All data were calculated from five mice per group for separate days.

After the administration of Coumadin $(0.40 \mathrm{mg} / \mathrm{kg} / \mathrm{day})$ for 3 days, the INR value increased to $7.28 \pm 1.08$ ( $4^{\text {th }}$ day). On the $8^{\text {th }}$ day the INR value for the Coumadin group became stable at $4.24 \pm 2.33$. When Coumadin and propolis 


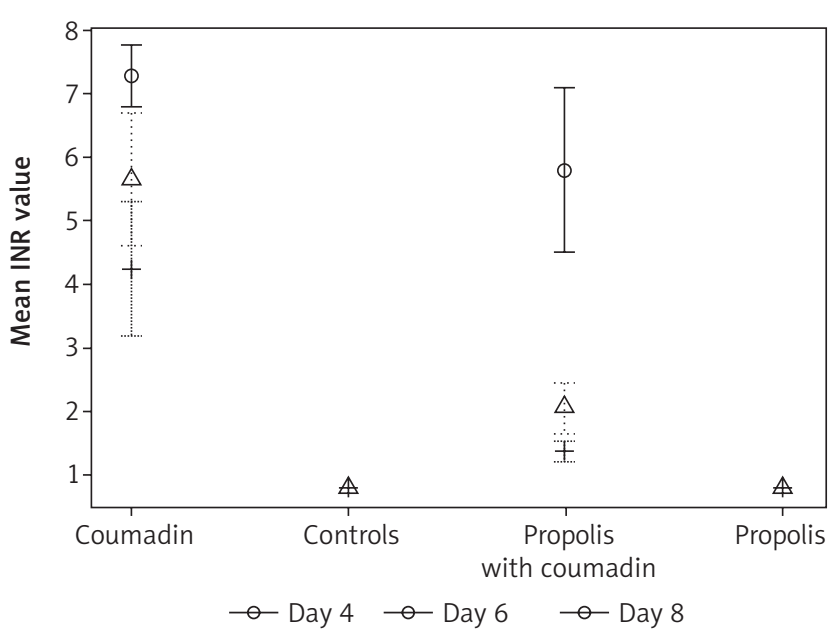

Fig. 1. All data were summarized with a plot of means

Circle: day 4, the first day of evaluating INR values; triangle: day 6 , the second day of evaluating INR values; plus: day 8 , the third day of evaluating INR values.

were administered concomitantly for 3 days, the INR value increased to $5.8 \pm 2.88$ ( $4^{\text {th }}$ day). Then, on the last day of the experiment ( $8^{\text {th }}$ day), the INR value gradually decreased to $1.38 \pm 0.37$ (Fig. 1).

These results demonstrate that propolis intake in combination with the Coumadin therapy dramatically reduced the anticoagulant effects of Coumadin in mice.

\section{Discussion}

Cardiovascular diseases are often associated with a high risk of recurrence and stroke. Today the most common cardiac dysrhythmia is atrial fibrillation. The standard treatment for this condition is oral anticoagulant therapy. For nearly a century, warfarin has been widely used for its anticoagulant effects exerted by inhibiting the activity of vitamin $\mathrm{K}$ epoxide reductase. Warfarin dosage is routinely checked with INR measurements. In recent years, the anticoagulant effects of warfarin have been affected by the intake of herbal products in concurrence with warfarin therapy, resulting in unstable INR values [11]. This has become a significant source of concern for health care providers because of the increasing concomitance of warfarin and herbal supplement use [12].

Propolis (bee glue) is a complex product combined with many different compounds (phenolic compounds, enzymes, and organic substances), which is used worldwide as a folk medicine $[13,14]$. A great number of experiments have reported protective effects of propolis, but current reports on drug interactions with propolis are lacking [15]. The only thing that is known about propolis is that it might increase the risk of bleeding by slowing down the blood clotting process. Skalli et al. reported that alkaloids contained in propolis could lead to adverse cardiovascular events [16].

Flavonoids are polyphenolic compounds with a wide distribution including plant foods. Several in vitro studies have shown that polyphenols such as resveratrol and the flavonoids quercetin and catechin inhibit platelet aggregation.
Tab. I. The main components of propolis from Düzce, Turkey

\begin{tabular}{|c|c|}
\hline Component & Percentage \\
\hline \multicolumn{2}{|l|}{ Alcohols: } \\
\hline $\begin{array}{l}\text { 2-Naphthalenemethanol, decahydro- } \\
\text { alpha.,.alpha.,4a-trimethyl-8-methylene-, } \\
\text { [2R-(2.alpha.,4a.alpha.,8a.beta.)]- }\end{array}$ & 1.47 \\
\hline$\alpha$-Bisabolol & 0.23 \\
\hline 2-Propen-1-ol,3-phenyl- & 2.05 \\
\hline 2-Methoxy-4-vinylphenol & 2.05 \\
\hline Benzyl alcohol & 0.34 \\
\hline Phenylethyl alcohol & 0.32 \\
\hline $\begin{array}{l}\text { 2-Phenanthrenol, 4b,5,6,7,8,8a,9,10-octahydro- } \\
\text { 4b,8,8-trimethyl-1-(1-methylethyl)-, (4bS-trans)- }\end{array}$ & 0.77 \\
\hline \multicolumn{2}{|l|}{ Aldehydes: } \\
\hline Vanillin & 0.41 \\
\hline \multicolumn{2}{|l|}{ Aliphatic acids and their esters: } \\
\hline 2-Propenoic acid, 3-phenyl-, phenylmethyl ester & 0.29 \\
\hline 6-Octadecenoic acid & 1.24 \\
\hline 9-Octadecenoic acid, ethyl ester & 1.35 \\
\hline Tetradecanoic acid, ethyl ester & 0.25 \\
\hline Hexadecanoic acid, ethyl ester & 0.39 \\
\hline 2-Propenoic acid, 3-(4-hydroxy-3-methoxyphenyl)- & 1.61 \\
\hline Dodecanoic acid, ethyl ester & 0.41 \\
\hline$n$-Hexadecanoic acid & 0.31 \\
\hline \multicolumn{2}{|l|}{ Carboxylic acids and their esters: } \\
\hline $\begin{array}{l}\text { 1-Phenanthrenecarboxylic acid, 1,2,3,4,4a,9,10,10a- } \\
\text { octahydro-1,4a-dimethyl-7-(1-methylethyl)-, } \\
\text { [1R-(1.alpha.,4a.beta.,10a.alpha.)]- }\end{array}$ & 0.42 \\
\hline Benzoic acid & 1.22 \\
\hline $\begin{array}{l}\text { 1,2-Benzenedicarboxylic acid, mono(2-ethylhexyl) } \\
\text { ester }\end{array}$ & 22.50 \\
\hline \multicolumn{2}{|l|}{ Cinnamic acids and their esters: } \\
\hline Benzyl benzoate & 0.49 \\
\hline p-Hydroxycinnamic acid, ethyl ester & 0.31 \\
\hline Trans-cinnamic acid & 0.74 \\
\hline 2,4-Dimethoxycinnamic acid & 0.86 \\
\hline \multicolumn{2}{|l|}{ Flavonoids: } \\
\hline $\begin{array}{l}\text { 2-Propen-1-one, 1-(2,6-dihydroxy-4-methoxyphenyl)- } \\
\text { 3-phenyl- }\end{array}$ & 4.82 \\
\hline $\begin{array}{l}\text { 4H-1-Benzopyran-4-one, 2,3-dihydro-5,7-dihydroxy- } \\
\text { 2-phenyl(Pinocembrin) }\end{array}$ & 16.08 \\
\hline $\begin{array}{l}\text { 4H-1-Benzopyran-4-one, 5-hydroxy-7-methoxy-2- } \\
\text { phenyl }\end{array}$ & 1.26 \\
\hline 4H-1-Benzopyran-4-one, 3,5,7-trihydroxy-2-phenyl & 2.54 \\
\hline $\begin{array}{l}\text { 4H-1-Benzopyran-4-one,5-hydroxy-2-4 } \\
\text { (4-hydroxyphenyl)-6,7-dimethoxy }\end{array}$ & 1.28 \\
\hline Chrysin & 6.94 \\
\hline \multicolumn{2}{|l|}{ Others: } \\
\hline $\begin{array}{l}\text { Naphthalene, hexahydro-1,6-dimethyl-4- } \\
\text { (1-methylethyl)-, [1S-(1.alpha.)]- }\end{array}$ & 0.34 \\
\hline 2-Naphthalenecarboxylic acid, 3,4-dihydro & 2.51 \\
\hline
\end{tabular}


Results obtained by incubating human or animal platelets with isolated flavonoids suggest that the antiplatelet properties may be attributed to the inhibition of TXA2 formation, thromboxane receptor antagonism, protein kinase $C$ activation, and phosphoinositide synthesis [17]. In the investigated propolis sample, we determined the ratio of flavonoids at $32.92 \%$. Although flavonoids have anticoagulant effects, the propolis sample applied in our research (obtained from Düzce, Turkey) suggested an opposite effect.

Furthermore, the compound "1,2-benzenedicarboxylic acid, mono(2-ethylhexyl)ester" was the major component of the used propolis; its antiviral, antimicrobial, antioxidant, and anti-inflammatory properties were discussed by Govindappa et al. [18]. The platelet effect of the propolis samples can be attributed to this compound, or it may be a synergistic effect of the other minor compounds. To analyze this effect, further research should be conducted by observing the effects of all the possible coagulant compounds after isolation.

To date, only two reports have been published about interactions between warfarin and bee products [19, 20]. However, no papers about interactions between propolis and warfarin have yet been published. In this study, we aimed to clarify the possible interactions of propolis and warfarin. For this purpose we used a mouse model. We examined whether propolis administration after warfarin decreased the anticoagulant effects of warfarin in mice using INR as an indicator. After the concomitant application of propolis and warfarin, a decline in the INR vales was observed in the mice. Based on our data (INR values obtained on successive days), we can underline that phytotherapy may have a negative effect on warfarin treatment. By reducing the effects of warfarin, it can lead to increased thromboembolic risk.

\section{Conclusions}

Although there are many studies on the protective and therapeutic effects of bee products, the use of these products without a detailed analysis of their contents could lead to serious health problems. More information is required about the possible interactions between these products and other agents. Further experiments are needed to better understand the precise mechanism through which propolis affects INR values. The fact that the chemical composition of propolis varies depending on the botanical source makes it difficult to standardize its use. Determining the effect of propolis compounds on INR values will provide more explanatory results; this requires more trials with different propolis samples. Another important issue is that physicians should ask their patients about propolis intake before starting warfarin therapy.

\section{Acknowledgments}

We thank Alp Yiğit Özdemir for his assistance with the animal model experiments.

\section{Disclosure}

Authors report no conflict of interest.

\section{References}

1. WRITING GROUP MEMBERS, Lloyd-Jones D, Adams RJ, Brown TM, Carnethon M, Dai S, De Simone G, Ferguson TB, Ford E, Furie K, Gillespie C, Go A, Greenlund K, Haase N, Hailpern S, Ho PM, Howard V, Kissela B, Kittner S, Lackland D, Lisabeth L, Marelli A, McDermott MM, Meigs J, Mozaffarian D, Mussolino M, Nichol G, Roger VL, Rosamond W, Sacco R, Sorlie P, Roger VL, Thom T, Wasserthiel-Smoller S, Wong ND, Wylie-Rosett J; American Heart Association Statistics Committee and Stroke Statistics Subcommittee. Heart disease and stroke statistics-2010 update A report from the American Heart Association. Circulation 2010; 121: e46-e215.

2. Fiumara K, Goldhaber SZ. A patient's guide to taking coumadin/warfarin. Circulation 2009; 119: e220-e222.

3. Bankova V, De Castro S, Marcucci M. Propolis: recent advances in chemistry and plant origin. Apidologie 2000; 31: 3-15.

4. Sforcin JM, Bankova V. Propolis: is there a potential for the development of new drugs? J Ethnopharmacol 2011; 133: 253-260.

5. Khosravi A, Shokri H, Darvishi S, Taghavi M. Immunomodulatory efficacy of ethanol extract of propolis on tumor-bearing mice with disseminated candidiasis. J Med Mycol 2014; 24: e143-e148.

6. Hoshino M, Ikarashi N, Tsukui M, Kurokawa A, Naito R, Suzuki M, Yokobori K, Ochiai T, Ishii M, Kusunoki Y, Kon R, Ochiai W, Wakui N, Machida Y, Sugiyama K. Menthol reduces the anticoagulant effect of warfarin by inducing cytochrome P450 2C expression. Eur J Pharm Sci 2014; 56: 92-101.

7. Çelemli ÖG, Hatjina F, Charistos L, Schiesser A, Özkırım A. More insight into the chemical composition of Greek propolis: differences and similarities with Turkish propolis. Zeitschrift für Naturforschung C 2013; 68: 429-438.

8. Gençay Ö, Salih B. GC-MS analysis of propolis samples from 17 different regions of Turkey, four different regions of Brazil and one from Japan. Mellifera 2009; 9: 17.

9. Foerch C, Arai K, Jin G, Park KP, Pallast S, van Leyen K, Lo EH. Experimental model of warfarin-associated intracerebral hemorrhage. Stroke 2008; 39: 3397-3404.

10. Fox J, Andronic L, Ash M, Boye T, Calza S, Chang A et al. Rcmdr: R Commander. R package version 1.5-4. 2009.

11. Izzo AA, Di Carlo G, Borrelli F, Ernst E. Cardiovascular pharmacotherapy and herbal medicines: the risk of drug interaction. Int J Cardiol 2005; 98: 1-14.

12. Rivera CA, Ferro CL, Bursua AJ, Gerber BS. Probable interaction between Lycium barbarum (goji) and warfarin. Pharmacotherapy 2012; 32: e50-e53.

13. Huang S, Zhang CP, Wang K, Li GQ, Hu FL. Recent advances in the chemical composition of propolis. Molecules 2014; 19: 19610-19632.

14. Bueno-Silva B, Alencar SM, Koo H, Ikegaki M, Silva GV, Napimoga MH, Rosalen PL. Anti-inflammatory and antimicrobial evaluation of neovestitol and vestitol isolated from Brazilian red propolis. J Agric Food Chem 2013; 61: 4546-4550.

15. Oršolić N, Benković V, Lisičić D, Đikić D, Erhardt J, Knežević AH. Protective effects of propolis and related polyphenolic/flavonoid compounds against toxicity induced by irinotecan. Med Oncol 2010; 27: 1346-1358.

16. Skalli S, Zaid A, Soulaymani R. Drug interactions with herbal medicines. Ther Drug Monit 2007; 29: 679-686.

17. Guglielmone HA, Agnese AM, Montoya SCN, Cabrera JL. Inhibitory effects of sulphated flavonoids isolated from Flaveria bidentis on platelet aggregation. Thromb Res 2005; 115: 495-502.

18. Govindappa M, Prathap S, Vinay V, Channabasava R. Chemical composition of methanol extract of endophytic fungi, Alternaria sp. of Tebebuia argentea and their antimicrobial and antioxidant activity. Int J Biol Pharm Res 2014; 5: 861-869.

19. Hurren KM, Lewis CL. Probable interaction between warfarin and bee pollen. Am J Health Syst Pharm 2010; 67: 2034-2037.

20. Cuzzolin L, Francini-Pesenti F, Zaffani S, Brocadello F, Pengo V, Bassi A, Benoni G. Knowledges about herbal products among subjects on warfarin therapy and patient-physician relationship: a pilot study. Pharmacoepidemiol Drug Saf 2007; 16: 1014-1017. 